\title{
Antivirüs Kentlerin Planlanmasında Yavaş Kent Yaklaşımı
}

\author{
Özge Ceylin Yildırım 1 \\ ORCID: 0000-0002-8721-9552
}

\author{
Gamze Özmertyurt ${ }^{2}$ \\ ORCID: 0000-0002-0813-5503
}

\section{Öz}

Tarih boyunca toplumları etkileyen deprem, sel, kuraklı, salgın, savaş gibi afetler toplumların yaşama mekanları olan kentlerin değişmesi ve dönüşmesine sebep olmuştur. Bu değişim kentlerin nasıl daha yaşanabilir ve dirençli olabileceğine dair travma sonrası ortaya çıkan kentleşme yaklaşımların beraberinde getirmiştir. Son dönemde tüm dünyayı etkisi altına alan Covid-19 salgınının boyutu, kapsamı ve hızı kentlerin derin bir dönüşüm sürecine girmesine neden olmakta ve sürdürülebilir, simbiyotik kentsel gelişimler hakkında temel sorunları ortaya çıkarmaktadır. Bu sorunlara çözüm olarak antivirüs destekli paradigma tabanlı bir yaklaşım geliştirmek gereklidir. Çalışma kapsamında bu yaklaşım salgının kent ve kentsel tasarım üzerinde potansiyel risklerini azaltmak ve yayılımın durdurmak için önerilen "Antivirüs kent" kavramının oluşumuna temel teşkil etmeyi amaçlamaktadır. Bu bağlamda 1980'lerde hem kentsel hem de sosyal bir hareket olarak ortaya çıkan "Yavaş Kent" hareketi ile, "Antivirüs kent"yaklaşımına, alternatif bir kent modeli oluşturmak adına ortak nitelikler ve ilkeler belirlenmeye çalışılmıştır. Literatürle yapılandırılmış bu çalışma, salgın sonrasında geleceğin kent stratejileri olarak önerilen Antivirüs kentlerin oluşumunda Yavaş Kent kriterlerinin büyük oranda uygun olduğunu göstermektedir. Böylece, Covid-19 salgını sonrası sağhlklı kent yaşamında geliştirilecek yeni önerilere rehberlik edebilecektir.

Anahtar Kelimeler: Covid-19, Antivirüs kent, Yavaş kent, kentsel planlama

\footnotetext{
${ }^{1}$ Arş. Gör., YTÜ, E-mail: ozgeceylinyildirim@gmail.com

2 Arş. Gör., YTÜ, E-mail: gamze_ozmertyurt@hotmail.com
} 


\title{
Slow City Approach in Planning Antivirus Cities
}

\author{
Özge Ceylin Yildırım ${ }^{3}$ \\ ORCID: 0000-0002-8721-9552
}

\author{
Gamze Özmertyurt ${ }^{4}$ \\ ORCID: 0000-0002-0813-5503
}

\begin{abstract}
Disasters such as earthquakes, floods, droughts, pandemics, and wars, which have affected societies throughout history, have led to the change and cities' transformation, which are living spaces. This change has brought with its studies on how cities can be more livable and resilient. The size, scope, and speed of the Covid-19 pandemic, which has recently affected the whole world, causes cities to enter a deep transformation process. As a solution to these problems, it is necessary to develop an antivirus-supported approach. The study' scope, this approach offers various suggestions to reduce the potential risks of the pandemic on the city and urban design and to stop its spread. With the "Slow City" that emerged as both an urban and a social movement in the 1980s, common characteristics and principles were tried to be determined for creating an alternative city model to the "Antivirus city" approach. Constructed with the literature, Antivirus, which is suggested as the city strategies of the future after the pandemic, shows that the Slow City criteria are largely appropriate in the formation of cities. Thus, it will be able to guide new proposals to be developed in healthy urban life after the Covid-19 pandemic.
\end{abstract}

Keywords: Covid-19, Antivirus city, Slow city, urban planning

${ }^{3}$ R. A., YTU, E-mail: ozgeceylinyildirim@gmail.com

${ }^{4}$ R. A., YTU, E-mail: gamze_ozmertyurt@hotmail.com

idealkent @ Kent Araştırmaları Dergisi (Journal of Urban Studies)

http://idealkentdergisi.com

Geliş Tarihi Received Date: 15.02.2021 Kabul Tarihi Accepted Date: 27.08.2021 


\section{Giriş}

Kentler, doğan, gelişen ve zaman içinde ölümü gerçekleşen yaşayan toplumsal organizmalardır (Park, 1915, s.577). Kent yaşamı, toplumsal yaşantının akışkanlığı ve devingenliği içinde var olduğundan, çevreden ve kentliden gelen birçok uyarana maruz kalmaktadır. Bu uyaranların başında sağlık kavramı gelmektedir. Kentlinin sağlık durumu iyi olduğu sürece kentin sağlığ da iyi olmaktadır (Belli ve Aydın, 2016, s.86). Sağlık hem yerel hem de küresel ölçekte kent ile doğrudan ilişkilidir. Kentlinin sağlık durumunu etkileyen en önemli değişkenlerden biri kentleşmedir. Son yıllarda kentleşmenin hızı, ölçeği ve kapsamındaki değişimin temel sebeplerinden biri küresel olguya dönüşmüş olmasıdır (Brenner ve Schmid, 2015, s.151). 2018 yılındaki kentsel nüfus \%55 iken 2050 yılında \%70'e çıkacağı tahmin edilmektedir (UN, 2019). Kentsel nüfustaki bu artış hayvan ve insan popülasyonlarının yaşam alanlarının iç içe geçmesini, insanların birbirleri ve diğer canlılarla etkileşimde bulunmasını artırmıştır. Bu etkileşim insanların evrimsel açıdan hazır olmadıkları ve bağışıklıklarının olmadığı hastalıklarla karşı karşıya kalmalarına neden olmuştur (Şeker, Özer ve Korkut, 2020). Bu hastalıklar hayvandan insana, sürekli ilişki içinde olan insanlardan insanlara bulaşıcı özellik göstermektedir. Bu durum sosyal ve mekânsal bir süreçtir, insanın ve doğal çevrenin hareketlilik derecesine bağlı olarak mekândan mekâna yayılmaktadır.

İnsan etkileşimlerini barındıran kentler, ulaşım ağları ve mahalle konfigürasyonları, enfeksiyon bulaşma oranlarını azaltma ve şiddetlendirme, bunların sıklığını ve ciddiyetini etkileme potansiyeline sahiptir. Kentsel mekânın biçimlenişi; yoğunluğu, arazi kullanımının heterojenliği, ulaşım altyapısı, konut türü ve kalitesi, hizmet tesisleri ve bunların konumlanışı kentlinin hareketliliğini, karma ve sosyal ağlarını şekillendirir. Kentsel mekân ve çevre davranışı, salgının yayılması arasındaki bağlantılara işaret etmektedir (Hayward ve diğerleri, 2020, s.3). Kentsel mekânın fiziksel biçimlenişi ve yaşam biçiminin olumsuz potansiyeli, sadece birkaç hafta içinde tüm dünyaya hızla yayılan COVID-19 salgınında görülmektedir (Sassen, 2020). Kentsel yapılı çevre biçimlenişi, salgınlardan önce önleme, sırasında ayırma yoluyla sınırlama, azaltma ve sonrasında acil durum planlaması ile gelecekteki riskleri dengelemek için karşı önlemlere açık bir şekilde planlanmalıdır (Megahed ve Ghoneim, 2020, s.1; Dietz ve diğerleri,2020, s.2).

Covid-19 bir ağ içindeki bilgisayar virüslerinin yayılmasına benzer hızla yayılarak, kente ve kentliye ciddi hasarlar vermektedir (Kindervag, 2020). Dijital dünyada virüs saldırılarına karşı yenilikçi çözümler tasarlamak ve her 
yeni teknolojiye uyarlamak için güvenlik katmanı eklemesi yapılmaktadır (Ahlefeldt, 2020). Ancak salgın hastalıklara karşı gerekli koruma sağlamak ve kent planlamada gerekli yaklaşımlar geliştirmek için yapılan araştırmalar yetersizdir (Megahed ve Ghoneim, 2020, s.2). Bu çalışma bu boşluğu gidermek için, dijital dünyadaki antivirüs düşüncesinden yola çıkarak, yaklaşan herhangi bir krizle karşı karşıya kalındığında kentlerin daha dirençli olması, salgının yayılmasını önlemek için Antivirüs kent planlamasının nasıl olacağına dair önerilerde bulunmaktadır. Bu bağlamda, küresel homjenleşmenin gerçekleştiği, hızın öneminin vurgulandığı günümüz kentlerine yanıt olarak ortaya çıkan yere özgü değerlerin korunduğu, yaşam kalitesinin artırıldığı, gerekli teknolojik altyapılarla kentsel morfolojinin desteklendiği sürdürülebilir bir yaşam biçimi olarak kabul edilen "Yavaş Kent" yaklaşımı (Cansaran,2018, s.902), alternatif bir vizyon olarak incelenmiştir. Çalışmanın ortaya koyduğu kent planlama önerilerinin mimarlar, şehir plancları ve otorite figürleri için salgına daha dayanıklı antivirüs kentleşme modellerine ve bu doğrultuda geliştirilecek politikalara katkı sağlayacağı düşünülmektedir.

\section{Tarihsel Süreçte Salgın Afeti Sonrası Kentlerdeki Değişim}

Kentlerin modernleşmesi ve teknolojinin gelişmesi, kentler arası ulaşım olanakların artırmış, bu durum mesafelerin kısalmasını sağlamış, hem de insanlarla birlikte hastalık taşıyıcı mikroorganizmaların daha hızlı ve tehlikeli şekilde yayılmasına neden olmuştur. Bu durum son olarak Covid-19 Pandemisi ile tüm dünyayı etkisi altına almıştır. Yaşanan salgına karşı kentlerin güçlendirilmesi, dirençli kılınması amacıyla geçmişteki salgınlarla nasıl başa çıkıldığını, yeni şekillenen kent planlarının hangi değişkenlere sahip olduğunu anlayabilmek gereklidir. Bu nedenle tüm insanlık tarihinde geniş çaplı etkisi olmuş salgın hastalıklar ve değişen şartlara uyumda kentsel düzenlemeler bu bölümün inceleme konusudur.

Salgınların meydana gelmesi mağaralarda az sayıda yaşayan ilk insanlığın M.Ö. 10.000 lerden sonra özellikle su kenarında yerleşik hayata geçmeye başlaması ve kalabalık gruplar oluşturarak kentleri oluşturmaya başladıkları dönemde görülmeye başlamıştır (Tekeli, 2020, s. 57). Salgınların seyrini etkileyen temel unsurlar tarihsel süreçte benzer özelliklere sahiptir. Bunlar, tarımsal toplulukların gelişimi yoluyla hayvanlardan insanlara geçen hastalıklar, yerleşik hayatın zorlukları, temiz suya ulaşamama, değişen koşullarla birlikte farklı bölgelerden insan gruplarının bir araya gelmesi ve kentleşme sonucu büyük insan grupları arasında hastalıkların yayılmasının hızlanması olmuştur (Özden ve Özmat, 2014, s.61). 
Salgın hastalıkların en bilinenlerden biri olan Veba, ilk çağdan günümüze kadar farklı evrelerde ortaya çıkmıştır. İlki 541'de Jüstinyen vebası denilen Konstantinopolis'te büyük oranda can kaybına neden olan veba salgınıdır. Tarihsel süreçte meydana gelen bulaşıcı hastalıklardan kayıtlara geçen ilk hastalıklardan olan ve toplumsal anlamda düzenlemelerin getirildiği cüzzam için ise 1179 'da 3. Lateran Konseyi toplanmıştır. 1200 yllına gelindiğinde Avrupa'da cüzzam hastalarının izole olmaları için yapılmış 19.000 leprosarya bulunmaktadır (Huber, 2006). 13-14. yüzyıla kadar farklı oranlarda bu salgınlar devam etmiş̧tir. 1347'de İpek yolu kervanları ile İslam coğrafyasında da yayılma gösteren vebaya "kara ölüm" denmiştir (Varlık, 2012, s. 176). 14. yüzyılda Çin ve Orta Asya'dan başlayan veba, 1347 yılında Avrupa nüfusunun yaklaşık üçte birinin ölümüne neden olmuştur. Hastalığın pirelerin insanları 1sırmasıyla veya enfekte insandan insana bulaştığı bilinmektedir. Avrupa'da yayılan veba salgını ise kentlerin yeniden düzenlenmesine sebep olmuştur. Mesafeleri rahatlatmak, yayılımı önlemek için dar sokaklar yerine geniş caddeler açılmış, karantina tesisleri açılmış, kamusal geniş alanlar düzenlenmiştir (Lubell, 2020). Osmanlı İmparatorluğu sınırları içerisinde ise salgınların artmasının sebebi 15. ve 16. yüzyılda fetihlerle birlikte hız kazanmıştır (White, 2013, s. 70). Salgının büyük oranda yayılmaya başladığı 17. yüzyılda ise Osmanlı topraklarında bulunan Balkanlar, Anadolu, Arap yarımadası salgından geniş ölçüde etkilenmiştir (Panzac, 2011, s.4). Kolera salgını ise 19. yüzyılda tüm dünyada olduğu gibi Osmanlı İmparatorluğu ve Anadolu coğrafyasını etkilemiştir. Önlem olarak bulaşıcı hastalık geçiren hastaların karantina altında kalmasını sağlamak için tahaffuzhaneler kurulmuştur (Bozan, 2015, s. 226).

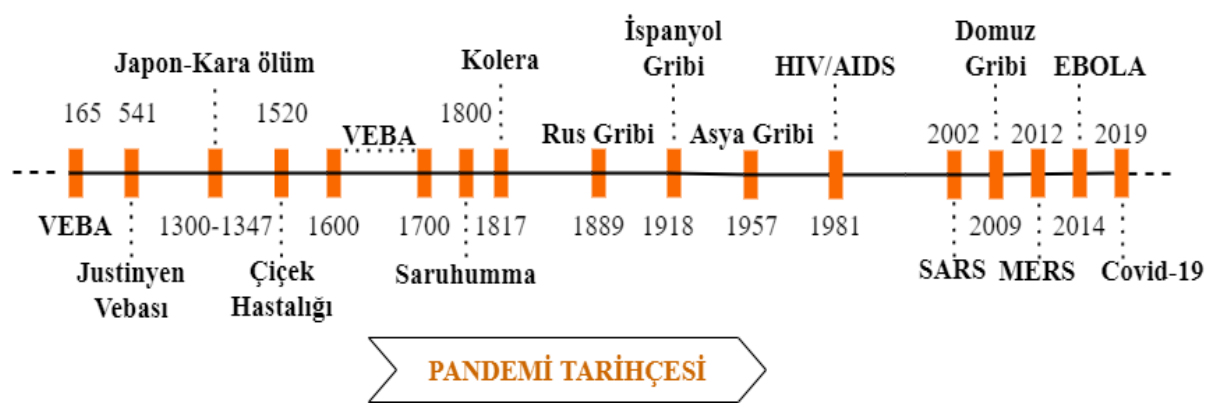

Şekil 1. Tarih boyunca pandemiler (Eltarabily, Elghezanwy, 2020, s.76 'dan üretilmiştir)

Salgın hastalıkların etkisinde yapılı çevrenin şekillendirilmesi özellikle son 200 yıldır şehir plancıları, mimarlar ve iç mimarlar tarafından antivirüs 
tabanlı planlama temelinde gerçekleşmiştir. Formda meydana gelen değişimler fonksiyonel ihtiyaçlara cevap verebilmenin yanında enfeksiyonel hastalıkların yayılmasını engelleyebilmek amacıyla da kurgulanmıştır (Ellin,1999).

19. yüzyılın 2. yarısında ise tarihteki en ölümcül salgın olan "İspanyol Gribi" tüm dünyayı etkisi altına almıştır. 50 milyondan fazla insanın ölümüne neden olan ve geniş coğrafyalara yayılan salgının temel sebebi 2 . Endüstri reformu olarak da bilinen teknolojik reformda demiryolu seyahatleri, kamusal mekanların eğlence sektöründe kullanılmaya başlaması gösterilmektedir (Crosby, 2003). Pandemiyi yavaşlatabilmek için alınan tedbirler, toplu taşımadan ziyade yürüyerek ulaşım, sokaklara belirli zamanlarda çıkma tedbirleri gibi günümüzde de kullanılan kentsel büyümeyi yavaşlatan ve kamusal yaşam alanlarını sınırlandıran tedbirler olmuştur (Eltarabily ve Elghezanwy, 2020, s. 76).

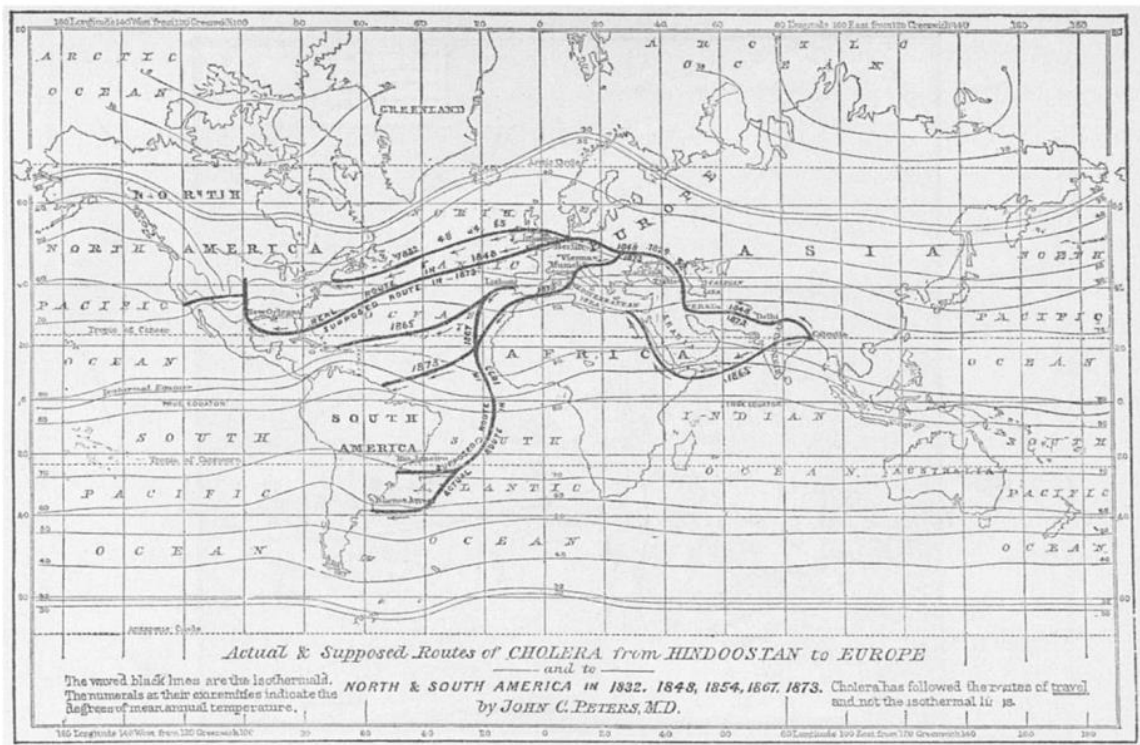

Şekil 2. 19. yüzyılda vebanın Hindistan' dan batıya yayılması (Huber, 2006, s.456)

Tarihsel süreçte pandemi neredeyse her dönemde tecrübe edilmiştir, günümüzde ise Covid-19 pandemisi ile bu durum 21. yüzyılda yeni bir boyut kazanmaktadır. Geçmişten çıkarılan dersler neticesinde karantina uygulamaları, kentsel açık alanları kullanıma yönlendirme, kapalı ve çok kişinin çalışacağı ofislerden ziyade daha bireysel çalışma olanakları sunulması hem mimaride hem de kentsel tasarımda yeni çözümleri beraberinde getirecektir. Teknolojinin bu süreçteki yeri ise yadsınamaz düzeydedir. 


\section{Covid-19 Pandemisi ile Kentleri Yeniden Düşünmek}

Kentler, dünya nüfusunun yarısından fazlasının yaşadığı, ekonomik büyümenin ve yeniliğin merkezidir. Bununla birlikte, kentsel yoğunluğun ve insan faaliyetinin fazlalığı, doğa ve insan kaynaklı afetlere karşı incinebilirliğini artmasına neden olmaktadır. Son yıllarda afetlerin kentler üzerindeki etkileri ve bunlarla başa çıkmak için gerekli planlama, iyileştirme ve uyum önlemleri üzerine çok sayıda araştırma yapılmış, geleceğin kentlerine dair öngörülerde bulunulmuştur (Sharifi,2020, s.2). Dünya Sağlık Örgütü'nün hizla yayılan Covid-19'u pandemi olarak ilan etmesiyle, insanlar kendilerini korumak ve salgının yayılım hızını azaltmak için birçok tedbir almaktadır. Bu küresel salgın, kişisel ve profesyonel yaşantıyı önemli ölçüde dönüştürmektedir. Kentsel planlama, mimarlık teorisi ve uygulamasının temellerini doğrudan etkileyerek yeni pandemi sürecinde ve sonrasında neler yapılması gerektiğine dair çalışmaların hız kazanmasını sağlamaktadır (Allam ve Jones,2020, s.3; Salama, 2020, s.6; Megahed ve Ghoneim, 2020, s.2).

Pandeminin oluşmasına neden olan küreselleşme, kentleşme hızı, nüfus artışı, küresel ısınma, iklim değişikliği ve ekosisteme yapılan müdahaleler gibi çeşitli etkenler, gelecekte pandemilerin sıklığını artırabileceğinden, pandemilerin altında yatan nedenler ve bunların kentler üzerindeki etkileri giderek daha karmaşık ve bilinmezliklerle dolu bir geleceğe işaret etmektedir (Connolly, Ali ve Keil, 2020 s.215). Bu bağlamda Covid-19 pandemisi ile kentlerin nasıl etkileneceğini anlamak ve çağın gerektirdikleri üzerinden geleceğin kentleri için öngörülerde bulunulması faydalı olacaktır. Bu kapsamda; mimarların, kent plancılarının ve birçok disiplinin virüsten koruma ile ilgili fikirleri nasıl sunabilecekleri veya mevcut alanları nasıl güncelleyebilecekleri konusunda birçok araştırma sorusu oluşturulmuştur (Tablo 1). 
Tablo 1. Covid-19 Pandemisi ile kentlere dair araştırma alanları ve soruları (Megahed ve Ghoneim, 2020, s.2-4'den üretilmiştir )

\begin{tabular}{|c|c|c|}
\hline & Araștırma Alanları & Araștırma Soruları \\
\hline 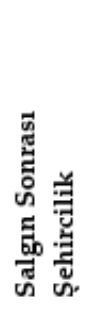 & $\begin{array}{l}\text { - Dijital dönüșüm ve uzaktan } \\
\text { çalıșma } \\
\text { - Merkezileșme ve yerinden } \\
\text { yönetim } \\
\text { - Șehirlerin yoğunluğu } \\
\text { - Yürüyüș, bisiklet ve toplu } \\
\text { tașıma }\end{array}$ & $\begin{array}{l}\text { Pandeminin ardından kentsel yașamı nasıl } \\
\text { yönetilmeli? } \\
\text { Pandemi daha fazla kentsel iyileștirmeye ilham verir } \\
\text { mi? } \\
\text { Enfeksiyonları azaltan șehirler tasarlayabilir miyiz? } \\
\text { Salgın sonrası dönem sosyal mesafeye dayalı yeni bir } \\
\text { șehircilik yaratır mı? } \\
\text { COVID-19 pandemi süreci merkeziyetçilik ve } \\
\text { yürünebilir şehirler için bir katalizör olabilir mi? }\end{array}$ \\
\hline
\end{tabular}

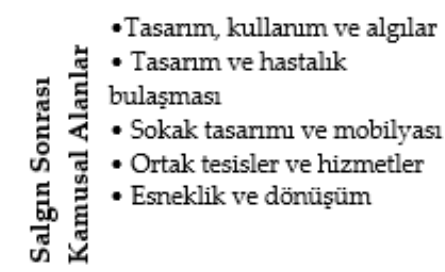

COVID-19'un gelecekteki kamu binalarmı ve alanlarmı nasil etkileyecek? Bu etkiler ve yansimalar gelecekte ne kadar sürecek?

Mobilya malzemeleri, ortak tesisleri ve hizmetleri ne olacak?

Ticari yapıların geleceği nedir?

Klimalı alıșveriṣ merkezleri devam edebilir mi?

\begin{tabular}{|c|c|c|}
\hline 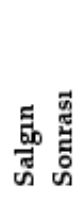 & $\begin{array}{l}\text { - Konut düzeni } \\
\text { - Alan ve yoğunluk } \\
\text { - Barnma ve güvenlik } \\
\text { - İç hava kalitesi }\end{array}$ & $\begin{array}{l}\text { Konutlarnn geleceği nedir? } \\
\text { Çalıs̆ma alanlarına daha iyi uyum sağlamak için uyum } \\
\text { sağlamalılar mı? } \\
\text { Kendi kendine yetmeli mi? } \\
\text { Teraslarımı, balkonlarımz ve çatılarımı nasıl } \\
\text { biçimlenmeli mi? }\end{array}$ \\
\hline 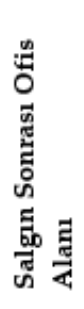 & $\begin{array}{l}\text { - Yerleșim ve tasarım } \\
\text { çözümleri } \\
\text { - Çalışma ve bekleme alanları } \\
\text { - Ortak tesisler ve hizmetler } \\
\text { - Ofislerdeki yoğunluk } \\
\text { - Bina yükseklikleri }\end{array}$ & $\begin{array}{l}\text { Ortak çalıs̆ma alanlarının ve açık plan ofislerin } \\
\text { geleceği nedir? } \\
\text { COVID-19 ofis yapılarının tasarımını değisstirebilir mi? } \\
\text { Yeni tasarım kriterlerine ihtiyaçları var m? } \\
\text { Yüksek katl yapıların geleceği nedir? } \\
\text { Sosyal mesafeyi gözeten sirkülasyon elemanları nasıl } \\
\text { olabilir? } \\
\text { COVID-19 sağlıklı konutlar ve sürdürülebilir binalar } \\
\text { için bir katalizör olabilir mi? }\end{array}$ \\
\hline
\end{tabular}

\begin{tabular}{|c|c|c|}
\hline \multirow{8}{*}{ 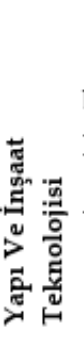 } & - Modüler yapı & İnşaat stratejisinin geleceği nedir? \\
\hline & - Standartlaştırılmış & COVID-19 tekniklerini değiştirebilir mi? \\
\hline & bileşenlerin & Daha modüler bir inşaat stratejisi benimsemeli \\
\hline & prefabrikasyonu & miyiz? Gelecekte daha fazla prefabrike ve \\
\hline & Hafif ve uyarlanabilir & standartlaştırılmış bileşenlere tanık olacak mı? \\
\hline & yapilar & Pandemi, şehirlerimizin dijitalleşmesini ve \\
\hline & Yapay zekā & hazlarımiz ce \\
\hline & & edecek mi? \\
\hline
\end{tabular}




\section{Alternatif Kent Modelleri}

Covid-19 pandemi süreci, küreselleşme ve kentleşmenin sonucu olarak kabul edilmektedir. Son araştırmalar, huzla genişleyen kentsel dokunun ve ağların potansiyel salgınların ortaya çıkmasında rol oynadığını iddia etmektedir (Boterman, 2020; Connolly ve diğerleri, 2020). Küreselleşme ile ulusların, hükümetlerin veya sağlık hizmetlerinin eşit olmaması, alt-ulusal gruplaşmaların oluşması ve mekânsal eşitsizliğin pandeminin yayılmasında ve etkisinin büyüklügünde önemli rol oynadığı görülmekte ve bu durumun dramatik sonuçlara neden olacaği düşünülmektedir (Ghosh, 2020; Alraouf, 2021, s.5).

Kentlerin gelecekte benzer salgınlara derhal tepki vermeye hazır olması gerektiği konusunda çalışmalar olsa da (Lee ve diğerleri,2020, s.18), bu hazırlığın nasıl şekillendirilmesi gerektiği hala açık bir sorudur. Özellikle sosyal mesafe, maske ve temizlik kurallarının bu dönemde hayat tarzımızdaki değişime neden olduğu tedbirler, kamusal mekanlarda da uymamız gereken bazı kuralları beraberinde getirmiştir. Bu amaçla yapılı çevremizin nasıl düzenlenmesi gerektiğini araştıran uzmanların daha önce öngörülen kent modelleri üzerinde çalışmaları yoğunlaşmıştır. Oluşum kriterleri önceden belirlenmiş olan bu kentlerin Post Pandemi döneminde alternatif kent modeli oluşumuna altlık oluşturması beklenmektedir. Bu amaçla literatürde çalışma alanları Akıllı kentler, Sağlıklı Kentler, Sürdürülebilir Kentlere doğru yoğunlaşmiştır (Allam ve Jones, 2021, s.2; Ratho ve John, 2021; Sinha ve diğerleri, 2020, s.3; Eltarabily ve Elghezanwy, 2020, s.77). Sadece pandemi sonrası dönemde kentlerin nasıl düzenlenmesi gerektiği değil, sokaklar, caddeler, rekreasyon alanları, konutlar gibi kent ile karşılıklı gelişim gösteren unsurların da yeniden tasarlanması ve düşünülmesi gerekmektedir.

Akıllı kentler, 21. yüzyılda endüstrileşmenin son basamaklarından biri olarak evrensel düzeyde tanınırlığını artırmaya başlamıştır. Yerel kullanım ve bilginin yerini dijital tabanlı sistemlerin alması kentlerin erişilebilir, pratik olma kapasitesini artırmıştır (Kunzmann, 2020, s. 21). Kentsel dijitalleşmenin gereklilikleri Covid-19 sürecinde daha fazla hissedilir olmuştur. Pandemi sürecinde bulaşıcılık oranların izlenebilmesi ve azaltılabilmesi adına interaktif teknolojilerin kullanıldığı kentlerde vaka sayılarında düşüşler sağlanabilmiştir (Eltarabily ve Elghezanwy,2020, s. 80). Akıllı kentlerin savunduğu ilkeler her ne kadar pandemi sürecinde hayatımızı daha yaşanabilir kılacak imkanlar sunsa da küreselleşmenin salgın hastalıkların çoğalmasında katalizör etkiye sahip olduğu geçmişteki vakalarda gözlenebilmiştir. Akıllı kent stratejilerinin yerelden ziyade küreselleşmeyi ve dijitale geçişi teşvik edici olması 
Antivirüs kent kavramını sorgularken bu kent modelinin zayıflıkları olarak gösterilebilir.

Sağlıklı kentler ise Covid-19 sürecinin evrensel sağlık krizi olarak değerlendirilmesi sebebiyle en fazla başvurulması gerekli kent modeli olarak algilanabilir. Sağlıklı kentler, özellikle kentsel sağlık hizmetleri altyapısının verimli hale getirilmesini amaçlamaktadır. Ayrıca interaktif teknolojileri de kullanarak izleme, karar verme araçlarını kullanmayı önermektedir (Ratho ve John, 2020). Sağlıklı kentler, devletler arası iş birliği, sosyal medya, gençlik organizasyonlarını bir araya getirici teknolojinin kullanımının teşvik edilmesi gibi kriterlerle de akıllı kent stratejilerinin bir parçasını oluşturmaktadır (Sinha ve diğerleri, 2020, s.3).

Pandemi sürecinde, küresel etkileşimi azaltmak ve kendi kendine yetebilen ekonomik çözümler ortaya koyarak toplumun direncini güçlendirmek büyük önem teşkil etmektedir. Bu bağlamda Yavaş Kentler; yerel çiftçileri, üreticileri, tüccarları, sanat gruplarını ve her türden sivil toplum kuruluşların destekleyerek ekonomik, sosyal ve çevresel zorluklarına adapte olurken yerel kimliği korumayı amaçlamaktadır. Nüfus yoğunluğu 50.000 altında olan Yavaş Kentler, büyük şehirlerden daha kolay izole edilebilir ve korunabilir. Aidiyet duygusunu ve dinamik sosyal etkileşimi besleyerek, kendi kendine yetmeyi hedefleyen, kentsel yoğunluğun az olduğu bu kentler Antivirüs Kentlerin planlamasına ve tasarlanmasına referans oluşturabilir.

\section{Yavaş Kentler}

Tüketim kültürü ve kentleşme politikaları, yere özgü değerleri, kültürel peyzajı, tarihi ve kültürel mirasları yok sayarak standart homojen topluluklar yaratmış ve doğal ekosistemlerin, tarihi ve kültürel değerlerin aşırı tüketilmesine neden olmuştur (Wheeler, 2004). Ayrıca sosyal yapıdaki bu değişiklikler, temel değerleri korumak için bir tepkiye ve "yer" kültürünün yeniden keşfedilmesi ve yaşatılması isteğine yol açmıştır (Knox, 2005, s.3; UN,2001). Bu bağlamda, kentlerde yaşanan olumsuzluklara çözüm bulmak amaciyla kentlere yere özgü değerlerin yeniden kazandırılması için Tanyeli (2007, s.13)'nin de ifade ettiği gibi “toplumsallığın mimarlık aracilığıyla dönüştürülebileceği inancını güden Yeni Şehircilik (New Urbanism) akımı" Yavaş Kent kavramına zemin hazırlamıştır.

Yavaş Kent hareketinin Yeni Şehircilik yaklaşımından en temel farkı saf modern şehircilik eleştirisinin ötesinde modernleşen ve küreselleşen kentlerin ruhlarını kaybetmeden nasıl olabileceğini sorgulamasıdır (Miele, 2008, 
s.140). Yavaş Kent 1986'daki "Yavaş Yemek (Slow Food)" hareketinden etkilenerek, 1999 yılında İtalya'nın öncülügünnde Almanya, Norveç ve İngiltere'nin destekleri ile ortaya çıkan bir kavramdır (Mayer ve Knox, 2006, s.322). Yavaş Kent üyeliği için 50.000'den az nüfusa sahip yerleşim alanlarının (1) çevre politikaları, (2) altyapı politikaları, (3) kentsel yaşam kalitesi politikaları, (4) tarımsal, turistik, esnaf ve sanatkârlara dair politikalar, (5) misafirperverlik, farkındalık ve eğitim için planlar, (6) sosyal uyum politikaları ve (7) ortaklıklar adı altında kategorize edilen 72 kriterin en az yarısının karşılanması gerekmektedir (Cittaslow International, 2021). İtalya'da başlayan bu hareketin üye sayısı gittikçe artmaktadır. 2021 yılı itibariyle 30 ülkede, 272 kent, "Sakin Kent" ünvanı almıştır (Cittaslow International, 2021).

Bu çalışma kapsamında Yavaş Kent kriterlerinden doğrudan Antivirüs kentlerle ilgili olan parametreler değerlendirilmiştir. İlk olarak hava kalitesi kontrolü, atık yönetimi, ışık kirliliği kontrolü ve alternatif enerji kaynakları gibi çevresel önlemler yerleşim alanının çevresel varlıklarını korumayı amaçlamaktadır. Bisiklet yollarının yapımı, toplu taşımayı teşvik etme ve bunların bisiklet yolları ile entegre edilmesi, yayalaştırma, kapsayıcı ulaşım ağının oluşturulması ile kentsel hareketlilik için kriterler belirlenmiştir. Kent merkezinde ürünlerin sürdürülebilir dağıtımı, yerel ürünlerin satışı için ticari merkez oluşumu gibi kentsel kalkınma programları ile özellikle sağlık merkezlerine ulaşılabilirlik gibi altyapı politikaları pandemi süreci ve sonrası için önemli parametrelerdendir.

Kentsel yaşam kalitesi politikalarına ait kriterlerden dirençli kent planlaması gibi yaklaşımlar dikkat çekmektedir. Salgın hastalıklar ve pandemi başta olmak üzere iklim değişikliği, doğal afetler, ekonomik krizler gibi 21.yüzyılda karşılaşılan krizlere yönelik olarak kentlerin dirençlerini artırmak Yavaş Kent hareketinin odak noktalarından biridir. Bu amaçla öncelikle yerel yönetimler, ulusal ve uluslararası ortaklıklarla desteklenen projeler yürütülmektedir. Bunlardan birkaçı;

- Kamu yapılarında enerji tüketimini azaltma,

- Yerel yenilenebilir kaynakların kullanımı,

- Verimli bitkilerin yetiştiriciliği,

- Ekosistem çeşitliliğini korumak ve üretkenliğini artırmak için permakültür ilkelerini benimsemek,

- Kentin kendine yeterliliğini göz önüne almak,

- Kullanıcı olan yerlinin her türlü yönetsel, planlama ve çözüm üreticiliğine katılım sağlamaktır (Cittaslow International, 2021). 
Bunlara ek olarak, kentsel peyzajın ve kültürel değerlerin korunması, sürdürülebilirliğini sağlanması, kentsel yaşanabilirliğin arttırılması, tarihi kentsel dokunun ve yerel üreticilerin desteklenmesi, yeşil alanların artırılması ve kent internet ağının sağlanması gibi kriterler kentsel yaşam kalitesi politikaları arasındadır.

Yerel üretimin korunması, yerel kültürel faaliyetlerin desteklenmesi, sağlık eğitimlerinin verilmesi, yerel yönetimlerin Yavaş Kent felsefesini benimseyerek yerel halkın ve ziyaretçilerin katılımını sağlaması, toplumsal eşitliğin gözetilmesi, yerlinin aidiyet duygusunun artırılması, farkındalık oluşturulması ve bilinç düzeyini artırılması gibi Yavaş Kentlerin birçok kriteri bulunmaktadır. Yavaş Kent için gerekli olan tüm bu kriterler, tüketim odaklı hızlı ve küresel kentlerin yapısını eleştirerek, salgın anında ve sonrasında daha sağlıklı, akıllı, sürdürülebilir; kentsel yoğunluğu düşük, yerel üretimin ve değerlerin önemini vurgulayan Yavaş Kentlerin alternatif olacağını ve yol göstericiliğini ortaya koymaktadır.

\section{Antivirüs Kentler}

Tarihsel süreçte birçok salgın hastalıkla mücadelede olduğu gibi tüm dünyayı etkisi altına alan Covid-19 pandemi süreci ile kentlerin, fiziksel yerleşimlerin, yönetimlerin ve aynı zamanda kentsel yaşam tarzının nasıl biçimlendirebileceği görülmektedir. Kentsel nüfus yoğunluğu, sosyo-ekonomik eşitsizlik, yaşam kalitesinin yetersiz olması, doğal yaşam alanlarının tahrip edilmesi, trafik sıkışıklığı, toplu taşıma kullanımı, yaya ve bisikletli olarak kentte var olabilme gibi kentsel hareketlilik problemleri, kent dokusunda yeşil alan eksikliği gibi faktörlerin salgının yayılmasında etkili olduğu vurgulanmaktadır (Li ve diğerleri,2020, s.1200; Lee ve diğerleri,2020, s.528). Farklı kentsel biçim ve tasarım faktörleri pandeminin dinamiklerini etkilemektedir. Bu bağlamda, Covid-19 salgın gibi krizlerinden kaynaklanan riskleri azaltmak ve önlemek amacıyla kent planlamasına potansiyel bir yön sağlamak için Antivirüs Kent planlama ve tasarım kriterleri önerilmektedir. Kent planlama ve tasarım kriterleri kentsel yoğunluk, hareketlilik, kamusal yaşam, konut, teknoloji olarak ele alınmaktadır.

\section{Kentsel yoğunluk}

Yerleşim bölgesine düşen yapı ve insanın varlığı olarak geçen kentsel yoğunluk (Keleş, 1980), kent morfolojisini şekillendiren, kentsel yaşam kalitesini belirlemesi açısından önemlidir. Kentsel yoğunluk, kişi başına düşen sağlık, eğitim, kültür gibi kamu hizmetleri ile kentsel açık ve yeşil alanlarda sahip 
olduğu alan miktarlarının belirleyicisidir. Bu bağlamda Antivirüs kentlerde, bir salgının yayılmasını etkileyen en temel faktörlerden biri nüfus yoğunluğu ve yapı yoğunluğu olarak ikiye ayrılan kentsel yoğunluktur.

Nüfus yoğunluğu fazlalığı, karma arazi kullanımı, yüksek yoğunluklu konut dokuları, yüksek ekonomik üretkenlik ve inovasyon yaratma olasılığı konularına odaklanan küresel, mega ve metropol kentsel söylemler 20.yüzyılın son dönemlerinden beri yaygındır (Sassen,2020). Kentsel yoğunluğun artışı, ekonomik sınıf ayrımları, kimliksiz ve tektipleşen kentsel dokular, hızlı ve kontrolsüz kentsel büyüme; sürdürülebilirliğe, dayanıklılığa, sosyal uyuma, kapsayıcılığa ve ekonomik firsatlara karşı önemli ölçüde risk oluşturmaktadır. Herhangi bir kriz anında bu riskin yıkıcı etkilerinin şiddeti artmakta, Covid-19 pandemisiyle tekrardan gündeme gelen krizde kentsel yoğunluğun ve kentleşme biçiminin salgının bulaşıcılığını kolaylaştırarak risk yoğunluğunu artırdığı görülmüştür (Hamidi, Sabouri ve Ewing, 2020,s.496).

Covid-19 pandemi süreci ile ulusal ve uluslararası kurum ve kuruluşlar kentlerle ilgili çeşitli projeler yürütmekte ve çalışmalar yapmaktadır. Bunlardan Paris en Commun (2020) (Şekil 3) ve Milano 2020 (2020) projelerinin stratejileri incelendiğinde, kentsel dokunun 15 dakikalık kümeler halinde bölümlenerek (15 dakikalık yürüme mesafesindeki şehir), kentlerin bir çeşit yapıbozumu sonucunda çeşitliliğin artırılmasının, kamusal alanların dengesiz dağılımının azaltılmasının ve kentsel yoğunluğunun yeniden keşfedilmesinin önemi ifade edilmektedir. 


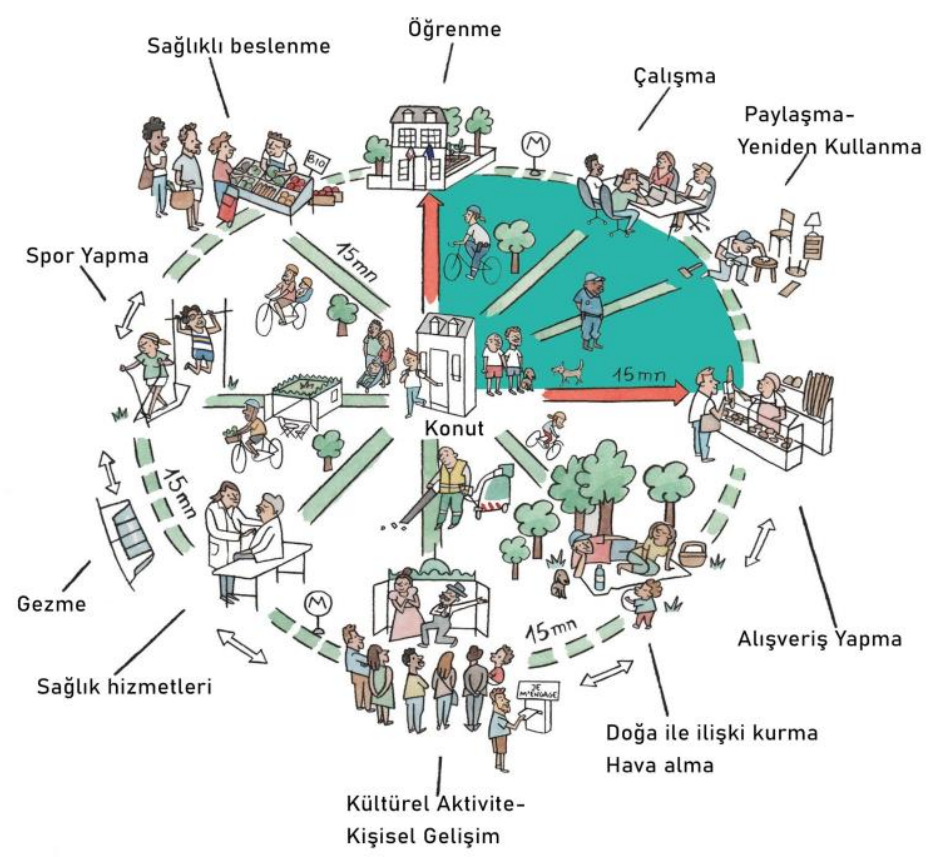

Şekil 3. Paris en Commun'un 15 dakikalık şehir konsepti (Paris en Commun, 2020)

Mevcut kentsel tipolojiler ile pandemi süreçlerinde yapılan kentsel çözümler incelendiğinde Antivirüs Kent bağlamında, kriz anında koruma ve savunma sistemini artırabilmek için yüksek yapı yoğunluğu ve aşırı kalabalık nüfusu önlemek amaçlı hedefler belirlenmiştir (Şekil 4). Bunlar;

- Yavaş Kentlerde olduğu gibi 50000 nüfusun altında daha az yoğunluklu kent,

- Sosyal mesafenin etkisi göz önünde bulundurarak yatay genişleme (Liu,2020, s.10; Megahed, Ghoneim, 2020 s.4),

- Yerel yönetimlerin ve yerel dokunun gücünü artırmak için tek bir merkez yerine ademi merkeziyetçilik yaklaşımı ile sağlık, eğitim gibi hizmet tesislerine de erişimin kolay olması,

- Kendi kendine yeten bir topluluk kavramı, çevreyi ve ekolojik sistemleri korumak için kentsel yoğunluk içinde kentsel tarımın da var olmasi,

- Yerel üretimin vurgulanması, büyük ölçekli tesislerin ve hizmetlerin entegrasyonunun sağlanmasıdır. 

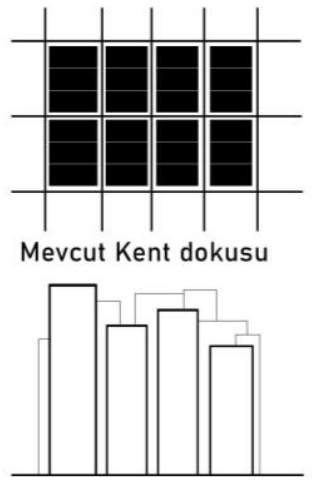

Mevcut düşey yoğunluk

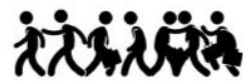

Mevcut nüfus yoğunluğu
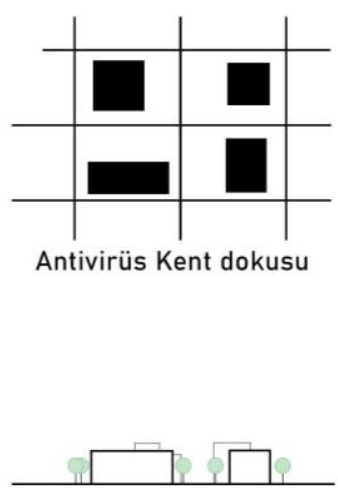

Düşey yoğunluk

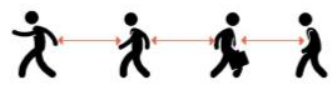

Nüfus yoğunluğu

Şekil 4. Mevcut ve Antivirüs Kent yaklaşımında kentsel yoğunluk diyagramı

Salgının yıkıcı etkisi sadece nüfus yoğunluğu ile ilgili değildir; yoğunluğun mekânsal karakteri ve kentsel makroform ve sinifsal dinamikler de önemli parametrelerdir. Bu nedenle küresel ekonominin neden olduğunu eşitsizliklerin etkisini azaltmak, yerel olanın gücünü ortaya çıararak kendi kendine yetebilen bir ekonomiyi sağlamak, kentsel yoğunluğu bu bağlamda ele alarak düzenlemek Antivirüs kentlerin temel amaçlarından biridir. Acil durumlarda değişip dönüşebilen kentsel alanlar, kendi içlerinde kendi kendilerine yeten kentsel yoğunluk kümeleri ve bunların arasındaki kolay erişilebilirlik Antivirüs kentlerin biçimlenmesinde önemli kriterlerdendir.

\section{Kentsel hareketlilik}

Covid-19 pandemisi, tüm dünyada geniş ölçüde etki etmiştir ve hala etkisini sürdürmektedir. Bu afetin küresel ölçekte sebep olduğu değişimler sadece insan hayatını değil, kentsel hareketlilikteki değişimleri de etkilemektedir. Seyahatlerin hem yerel hem de uzun mesafeli kısitlamalarla kesintiye uğraması da insanların hareketlilik davranışını büyük oranda etkilemiştir. Örneğin İstanbul için 3 Ocak- 6 Şubat 2020 aralığında yapılan ölçümlerde insan hareket kısıtlaması perakende ve rekreasyon alanları için yaklaşık \%81 oranında bir düşüş yaşanmıştır. Diğer yüksek oranda düşüş yaşayan alan ise transit istasyonlarda (ör. metro, otobüs ve tren istasyonları) \%61 oranında yaşanan düşüştür (Google, 2021). 
Covid-19 sonrası kent ulaşımında yapılması gereken düzenlemeler için bu sürecin potansiyel bir fırsat olacağını ileri süren optimistler, daha geniş caddeler açılabilmesi, yolcu ve bisiklet kullanıcıları için daha fazla cadde kullanım imkânı sunacak değişimlerle daha sürdürülebilir kentlerin tasarlanabileceğini düşünmektedir (Nieuwenhuijsen, 2020, s. 4). Salgın sürecinde ve sonrasında kentsel hareketliliğin tasarlanabilmesi için öncelikli amaç salgının yayılmasını engellemek, sonra da bu şartlarda yaşam koşullarını sürdürebilmek için etkileyici rehabilitasyon çalışmaların devam ettirmektedir.

Covid-19 sonrası kentlerin düzenlenmesinde plancıların ve tasarımcıların üzerinde durduğu konular;

- Sağliklı kentler için daha az motorlu araç kullanımı,

- Fiziksel mesafenin sağlanabilmesi için yaya yollarının genişletilmesi, meydan düzenlemelerinin yapılması,

- Online siparişler için kaldırımlarla birlikte kurye park alanlarının tasarlanması,

- Kamu tesislerinin girişlerinde, kuyruk sırası olacak yerlerde genişletmelerin yapilması,

- Sokak ve caddelerdeki hareketliliğin nasıl ve hangi yönde olacağına yönelik çalışmaların artırılmasıyla riskli alanların düzenlenmesi gerekliliği,

- Toplu taşıma araçlarında yoğunluğun azaltılması ve dağınık oturma düzeni kurgulanması, terminal giriş ve çıkışlarında sıkışıklık ve teması azaltabilmek için ek alanların sağlanması,

- Otoparklarda, taksi durakları, istasyonlarda taşınabilir dezenfeksiyon istasyonlarının kurulması,

- Mikro mobilite araçlarının (e-scooter, bisikletler, v.b.) kullanımı ve altyapıların düzenlenmesi,

- Antropometrik, bilişsel ve yetkinlik düzeyindeki (görme, işitme, hareketlilik) bireylerin özellikleri anlaşılarak evrensel tasarım ilkelerinin benimsenmesidir (Honey-Rosés ve diğerleri, 2020, s. 8; Hawkins, 2020; Null ve Smith, 2020; Rueda, 2019, s. 140).

Kısıtlı sosyal yaşam, ulaşım aktivitelerindeki düşüuşler, yayalaşma hareketlerinde artışın sağlanması, bisiklet gibi mikro mobilite araçların kullanımının bireysel ve sağlıklı olması sebebiyle daha fazla tercih edilme potansiyeli antivirüs kentler için yapılması önerilen değişikliklerdir (Şekil 5). Bu çerçe- 
vede konuya bakıldığında bulunulan alanda yaşamanın, yerel ölçekte gelişmenin, endüstri devrimi sonrası yaşanan küresel trafiğin yavaşlatılmasının önemi ortaya çıkmaktadır.
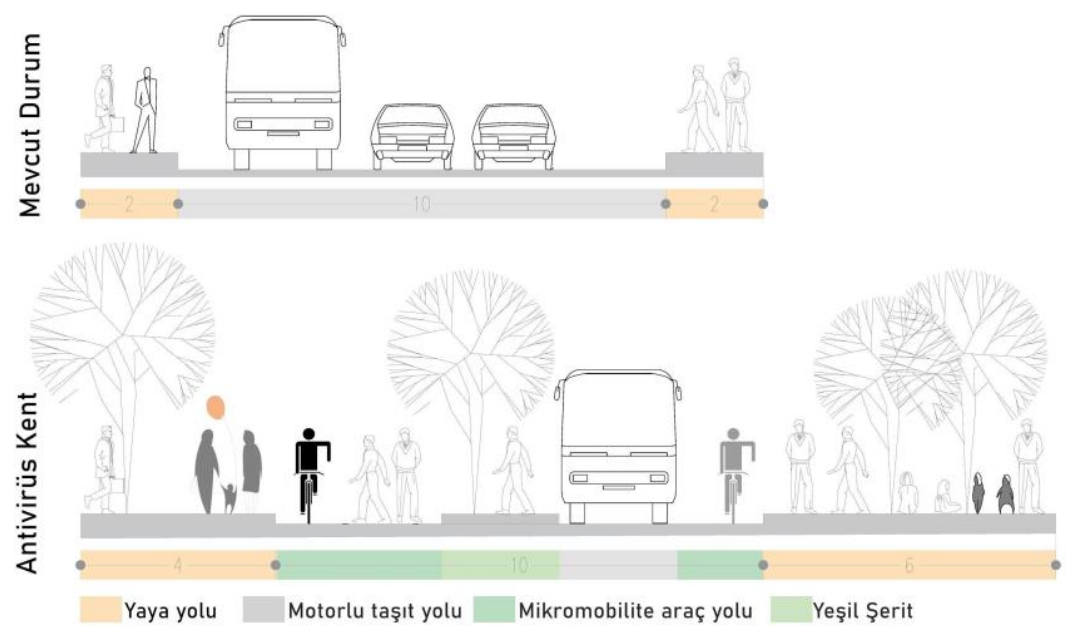

Şekil 5. Mevcut ve Antivirüs Kent yaklaşımında kentsel hareketlilik

\section{Kamusal Alanlar}

Kamusal alanların düzenlenmesi, Covid-19 ile kentsel tasarımda değişecek olan kriterlerden biri olmuştur. Özellikle fiziksel mesafe kurallarına uyulması ve daha bireysel yönelimi teşvik edici önlemler alınması halk sağlığını korumada kamusal alanların kısıtlanmasına neden olan itici güçlerdir. Yapılacak yeni kent tasarımlarında veya alternatif kent stratejilerini geliştirmede bazı temel sorulara cevap aranacaktır. Kriz anında yapılan dönüşümlerin ne kadarının sonraki süreçte kalıcı olacağı, sokakların, yeşil alanların, kamusal mekân ve kentsel boşlukların tasarımlarının nasıl olacağı bu tartışmalardan bazılarıdır.

Yeşil alanların modern toplumdaki psikolojik gerilimi hafifletici kentsel rehabilitasyon alanları olmasının dışında pandemi sürecinde ve sonrasında da fiziki yıpranmadan ziyade, psikolojik yıpranmayı hafifletici etkisi antivirüs kentler için önemli bir bileşendir. Kentin havasının temiz olmasının sağlanması, yeşil alanlara yönelimin teşvik edilmesi ve kişi başına düşen yeşil alanların artırılması gereklidir (Kemnitz, 1997, s. 114). Kentlerdeki yeşil alanların toplumun fiziki aktivitelerini gerçekleştirebileceği, kapalı ortamın virüs yayılımını artırıcı etkisinden ziyade bu dönemde açı alanların daha tercih edilebilir olması, sosyal mesafe kuralı gözetilmesi gerekliliği, ruhsal travmanın etkisini hafifletme gibi sebepler yeşil dokunun kentsel alanlarda hatta daha lokal seviyede artırılmasını zorunlu kılmaktadır. 
Yayalaşmanın teşvik edilmesi, bisiklet kullanımının artırılması ile kullanıcı ihtiyaçlarını daha iyi karşılayacak alternatif cadde tasarımlarının yapılması ve vatandaşların açık hava egzersizi, rekreasyon taleplerini karşılamak için açık ve yeşil alanlar gereklilik olmaktadır (Honey-Rosés ve diğerleri,2020, s. 10).
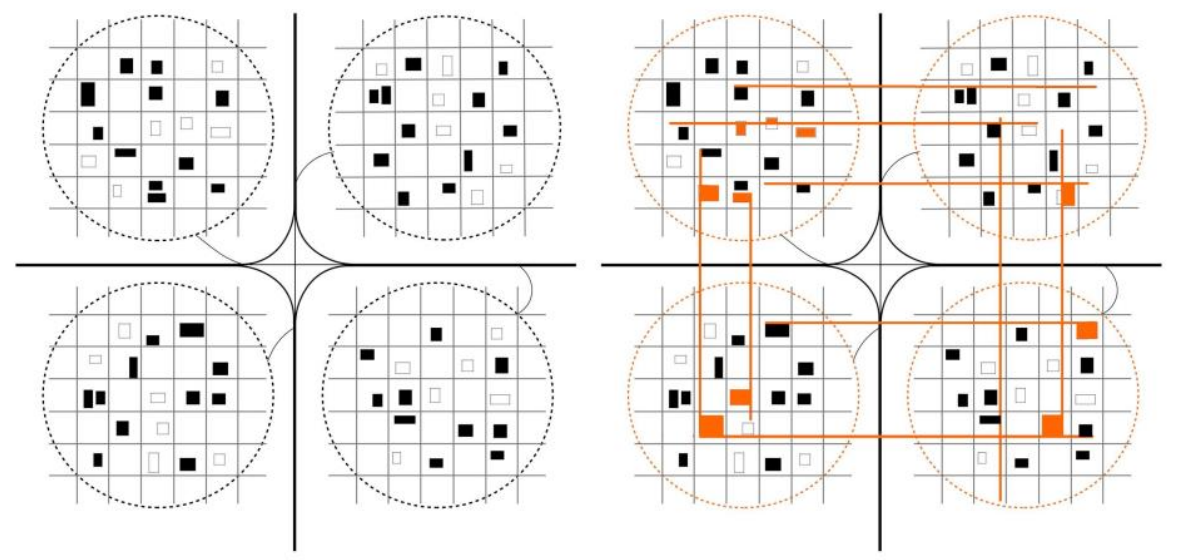

Şekil 6. Esnek, erişilebilir, eşit kentsel yoğunluk konsepti

Pandemi süresince acil ihtiyaçlar doğrultusunda stadyum ve konferans merkezleri, hastaneler için ek mekân arayışlarına çözüm sunan hızlı ve pratik dönüşümler geçirmiştir (Hassanzadeh-Rad ve Halabchi, 2020, s.2). Bu durum esnek ve ihtiyaca uygun olarak düzenlenebilen tasarım algısının antivirüs kentlerde önemli bir kriter olduğunu göstermiştir (Şekil 6). Kültürel aktiviteleri kısıtlamak, sosyal davranış biçimi gelişmiş olan insan topluluğu için olumsuz psikolojik, sosyal, travmalara sebep olacaktır. Bu nedenle antivirüs kentlerde kamusal alanları oluşturan geniş caddeler, bu caddeler üzerindeki mekânlar ve meydanlar ile nüfus yoğunluğu arasındaki dengenin kurulması yerel yönetici ve tasarımcıların iş birliği ile geliştirilebilir.

\section{Konut Tasarmı}

İnsan yaşamıyla kenetlenmiş bir olgu olan konut, ait olduğu grubun karakterini, inancını, yaşam tarzını, sosyal yaşantını, çevre tercihlerini, imgelerini ve kişinin kendi özünü, eğilimini, bireyin kişiliğini yansıtır. Kendi kendini tecrit etme, karantina uygulamaları çoğu ülkede pandemi sürecinde alınan önleyici politikaların ve önlemlerin başında gelmektedir. Bu durum, konutun tanımlamalarını ve işlevselliğini değiştirmiştir. En çok vakit geçirilen ev-iş, ev-okul alanlarının mekânsal özelliklerinin iç içe geçtiği ve salgının sürecinin deneyimlendiği alanlardan biri haline evrilmesine neden olmuştur 
(Megahed ve Ghoneim,2020, s.4; Capolongo ve diğerleri,2020, s.15). Covid19 ile konut, bireylerin ve ailelerin psikolojik, manevi, sosyal ve kültürel yönlerini, geleneklerini ve göreneklerini destekleme rolü yeniden şekillenmiştir.

Covid-19 karantina sürecinde konutlar ile ilgili karşılaşılan zorluklardan genel olarak aşağıdaki gibi özetlenebilir.

- Çok işlevliliğe uygun olmayan mekânsal kurgular (uyku, çalışma, çalışma, çizim ve oyun ...)

- Mekanların organizasyonlarında ve hacimlerin esneklik sağlayamaması,

- Konuta girişte yetersiz alan nedeniyle sterilizasyon işleminde zorluklar,

- Konutta yaşayan bireylerin kişisel alanlarının yetersiz olması,

- Yarı açık mekanların dönüştürülmesi (Balkon, teras, çatı ...),

- Doğal aydınlatma kalitesi ve doğal havalandırmanın yetersizliği,

- Yüksek katlı konutlarda insan yoğunluğu fazlalığı, sağlık ve hijyen önlemlerinin alınmaması,

- Gürültü ve mahremiyet nedeniyle ortak kullanım alanlarının problemli kullanımları ile ilgili sorunlarla karşılaşılmaktadır.

Covid-19, konutların kullanım yoğunluğu, işlevsel ve anlamsal biçimi değiştiğini göstermektedir (Eltarabily ve Elghezanwy, 2020, s.79; Megahed ve Ghoneim,2020, s.6; Bettaieb ve Alsabban, 2020, s.4). Bu bağlamda Antivirüs kentlerin konut tasarımlarının öncelikle, çok işlevliliğe uygun mekansal organizayonlarla minimum bütçe ve zaman dilimlerini kullanarak farklı işlevlere uyum sağlayan esnekliğe sahip olması üzerine odaklanılmıştır. Mekânın esnekliği kullanıcısının algısından etkilendiği göz önünde bulundurularak, yapısal, işlevsel ve kültürel esneklik olarak tanımlanmaktadır (Şekil 7) (Gilani ve Turker, 2020, s.158-162).

- Yapısal esneklik için genişleme, daralma, alanların dikey veya yatay olarak bölünmesi veya gelecekteki değişiklikler için açık planlı mekânsal ve yapısal sistemler önerilebilir.

- İşlevsel esneklik; mekânsal organizasyonu değiştirerek çeşitli mekânsal şemaları ve eylemleri barındırmak için mekânları değiştirme imkânı sunulmasıdır. Donatı elemanları ile esneklikler sunarak farklı mekansal ilişkiler önerebilir.

- Kültürel esneklik için, kullanıcının ilgi alanları, zevkleri ve tercihlerine göre esnek tasarım ile, mikro düzeyde sürdürülebilir konutlar önerilebilir. 

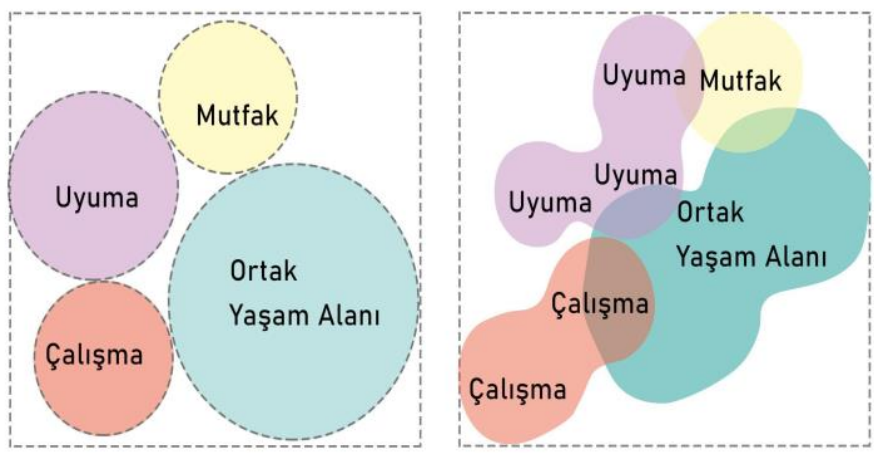

Şekil 7. Mekansal organizasyonların esneklik konsepti

Konut tercihleri mahalle ve bölge ölçeğinde değişiklikleri beraberinde getirmekte, bireylerin davranışları ve yaşam tarzları üzerinde önemli etkileri olan konutların sosyal mesafe, yiyecek üretme, doğal ışık, hava ve doğanın iyileştirici gücünden faydalanma imkânı sunması gerekmektedir. Bu durum apartmanlardaki yaşamın, az katll, bahçesi olan konutlara evrilmesi, kent mekânından konut mekanına geçişteki süreçte temassız erişim sağlanması gerekmektedir. Konut tasarımı çözümlerinde daha geçiş ve esnek yaşam alanlarına, sirkülasyon alanlarındaki asansör, koridor, merdiven gibi çözümlerde sterilizasyon imkanlarını sunan; kullanıcılar için esnek ve uyarlanabilir alanlar sağlamak, konutları daha sürdürülebilir hale getirebilir, değişen ihtiyaçlara ve değişen yaşam tarzlarına uyum sağlayabilir. Ayrıca barınma eşitsizliği noktasından da durum incelendiğinde nüfus yoğunluğunun yüksek olduğu, sosyo-ekonomik durumun düşük olduğu kentsel çöküntü bölgelerinde salgının daha hızlı yayıldığı görülmektedir. Burada yaşayan halkın yaşam standartlarını iyileştirecek ve bilinçlenmelerini teşvik edecek önlemler alınması yerel yönetimler ve diğer sivil toplum kuruluşlarının gündeminde olmalıdır.

\section{Teknoloji}

Antivirüs kentlerin tasarım ve planlama kriterleri toplumun yaşam kalitesini iyileştirmeyi, sosyo-kültürel faaliyetleri artırmayı, toplumun refah seviyesini yükseltmeyi, dinamik ekonomik gelişmeleri desteklemeyi ve ekolojik dengeyi korumayı hedeflemektedir. Bu hedeflerin gerçekleştirilmesi ve sürdürülebilirliğinin sağlanması için teknolojinin ve dijital araçların kullanımı, bunlarla desteklenmesi büyük önem arz etmektedir. Gelişmiş teknolojik sistemler ve iletişim teknolojileri kullanılarak kentlinin yaşamlarının iyileştirilmesi, bölgesel, ekonomik ve çevresel faktörlerin optimize edilmesini 
anlamında emniyet, ulaşım, eğitim, sağlık, turizm, kamu politikası gibi birçok avantaj sağlamaktadır (Batty, 2014; Khatoun ve Zeadally ,2016, s.48). Kentsel mekânda bilgi ve iletişim teknolojileri, nesnelerin interneti, sensörler, yapay zekâ teknolojileri, büyük veri, mobil cihazlar gibi teknolojiler ile alg1lama, bilgi, veri analizi, iletişim ve ağ teknolojilerinin artması ile kentin fiziksel ve işlevsel yapısında birçok açıdan yenilikçi öneriler geliştirmektedir (Bibri ve Krogstie, 2017, s.209). Covid-19 pandemisi ile enfekte olmuş kişileri izlemek için mobil cihazların ve uzak sensörlerin kullanıldığı dijital veri kaynakları, bu salgınla başa çıkmak için yardımcı olmaya katkıda bulunabilir. Çin'in Covid-19 pandemisi ile ilgili deneyiminde akıllı sağlık hizmetleri ve teknoloji firmalarının "büyük veri" analizleri ile virüsün yayılmasını takip ederek, önlemek için teknolojinin gücünden yararlandığı bilinmektedir (Eltarabily ve Elghezanwy, 2020, s.81). Çevresel, sosyal ve kentsel bağlamda sürdürülebilirliğin sağlanması, yeni teknolojik gelişmelerin kentsel yaşama entegre edilerek mekân kalitesinin artırılması, enerji verimliliğinin sağlanması gibi durumlar için bilgi ve teknoloji odaklı kentsel altyapılar Antivirüs kentlerin önemli bileşenlerinden biridir.

\section{Değerlendirme ve Sonuç}

Kentler, dünya nüfusunun çoğunluğunun barındığı, ekonomik büyüme ve yeniliğin merkezidir. Bununla birlikte, kentsel yoğunluk, kentleşme hızı ve beraberinde ortaya çıkan insan ve doğa kaynaklı birçok riske karşı kentler savunmasız hale gelmektedir. Bu risklerden biri olan pandemilerin, insanlık tarihi boyunca, kentler ve kent planlama yaklaşımlarında önemli değişiklere neden olduğu görülmektedir. Bu kapsamda mevcut Covid-19 pandemisi ile kentlerin sağlık davranışları ve hastalığın bulaşıcılığı üzerindeki önemli etkisi yeniden ortaya çıkmış, mimari ve kentsel planlama anlayışlarındaki değişimi zorunlu kılmaktadır. Pandemi sonrası gündelik hayat pratikleri eskisi gibi olmayacak; sosyal alışkanlıklar, kültürel aktiviteler değişime uğrayacaktır. Kentler, salgın ile baş etmeye çalışırken, nasıl planlanması ve yönetilmesi konusunda çok sayıda sorunun cevaplanmasına ve yeni bakış açılarının ortaya konulmasına ihtiyaç duymaktadır. Kent planlamasında teknolojik, sürdürülebilir, sağlıklı ve bütünleşik yaklaşımlara ihtiyaç olduğu görülmektedir. Bu bağlamda geleceğin kent tanımlarından Akıllı Kentler, Sağlıklı Kentler ve Sürdürülebilir kentler başta olmak üzere kentsel yoğunluğun, kamusal alanların, hareketliliğin, ekolojik yaklaşımların, konut erişilebilirliğinin, yeşil alanların tartışıldığı alternatif kent modelleri gündeme gelmektedir. 
Sadece Covid-19 pandemisi ile baş edilmesinde değil, gelecekte ortaya çkabilecek yeni salgınlar ve krizler için mimaride, kent planlamada, yerel ve uluslararası yönetimlerde yeni standartların geliştirileceği öngörülebilir. Pandemi ile sosyal, ekonomik, kültürel, kentsel birçok etkiye neden olmaktadır. Ancak bu etkilerin gelecekteki sonuçları belirsizdir ve konu ile ilgili daha fazla çalışma yapılması gerekmektedir. Geçmiş pandemilerde olduğu gibi geçici ve parçacıl kentsel çözümler, 21. yüzyılda ortaya çıkan ve geleceği spekülatif olan Covid-19 pandemisi ile gelecekteki krizler için yeterli değildir. $\mathrm{Bu}$ bağlamda çalışma kapsamında, kentlerin salgın gibi kriz anlarında çok katmanlı koruma yaklaşımı ile savunma ağına sahip olması için Antivirüs yaklaşımından yola çıkarak "Antivirüs Kent" yaklaşımı önerilmektedir. Kentin biçimlenişi, yoğunluğu, sokak tasarımları, kamusal ve yeşil alanlar, konutlar ve teknolojik yaklaşımlar bağlamında ele alarak proaktif kent modelidir. Bu kent;

- Kentsel yoğunluğun dengelenmesi,

- Sosyal mesafenin sağlanmasına olanak verecek kamusal ve yeşil alanların artırılmasi,

- Kentteki yaşam kalitesinin yükseltilmesi,

- Sürdürülebilir kentsel çevrenin yaratılması,

- Kentsel mekânın kimliğinin korunması ve toplumda aidiyet duygusunun yükseltilmesi,

- Kolay erişim ve dolaşımın sağlanması ile kentsel canlılı̆̆ın ve güvenli ortamların yaratilmasi,

- Yerel ekonomik gelişmelerin desteklenmesi,

- Doğal çevrenin korunması ve sürdürülebilmesi,

- Mikromobilite araçların kullanımı,

- Dijital altyapı sistemlerinin kurulması,

- Bilgi ve iletişim teknolojilerin kentsel mekâna entegrasyonun sağlanması,

- Çok işlevselliğe olanak tanıyan özel, yarı özel ve kamusal alan organizasyonlarına olanak sağlayan esnek tasarım yaklaşımları,

- Kentsel peyzajın, tarihi ve kültürel değerlerin korunmasını hedeflemektedir.

Antivirüs kentlerin son dönemde tartışılan alternatif kent arayışlarında daha önce çalışılmış olan Akıllı Kentler, Sürdürülebilir Kentler, Sağlıklı Kentlerin kriterlerinin uygunluğu araştırılmıştır. Çalışmada önerilen alternatif kent modeli ise Yavaş Kentler bağlamında tartışılmıştır. Yavaş kentler hızlı kentleşme ve küreselleşmeye karşı ortaya çıkmış, daha yerele dönük, üretim- 
tüketim dengesinin sağlandığı, sosyal, kültürel değerleri gelişmiş, enerji koruma yaklaşımı ve kentsel sürdürülebilirliğe uygun bir yaklaşım olması sebebiyle antivirüs kent modeli olarak bir alternatif oluşturmaktadır. Yavaş kentlerin gelecek antivirüs kent planlama stratejilerinde taban modeli olarak kullanılabilecek nitelikte kriterler barındırması, çalışmada alternatif kent modeli olarak yeni bir yaklaşım oluşturulmasını sağlamıştır. Çalışmada önerilen Antivirüs kent planlamasına alternatif oluşturacağ düşüncesi ile Yavaş kent modeli ile karşılaştırılmıştır (Tablo 2).

Bu bağlamda antivirüs kentlerin planlamasında öne çıkan kriterler; kentsel yoğunluk, kentsel hareketlilik, kamusal alanlar, konut tasarımı ve teknoloji olarak belirlenmiştir. Yavaş kentlerin nüfuslarının 50.000'den az olması gerekliliği ve dışa bağımlı tüketim anlayışından ziyade tarımsal üretimi teşvik etmesi, nüfusunu düzenleyebilecek yaklaşımları barındırmaktadır. Motorlu taşıt trafiğine izin vermeyen, mikromobilite araçlarının kullanımını teşvik etmesi, bisiklet kullanımını özendirmesi ve buna uygun kentsel düzenlemelerin yapılması kentsel hareketliliğin kısıtlanmasını sağlamaktadır. Böylece toplu taşıma kullanımında olduğu gibi bireylerin aynı anda bir araya gelmesini önleyerek, bulaşıcılık oranını düşürecek bir yaklaşım sunmaktadır. 
Tablo 2. Antivirüs Kent yaklaşımı ve Yavaş kentler

\begin{tabular}{|c|c|c|}
\hline & ANTİVİRÜS KENT & YAVAŞ KENT \\
\hline 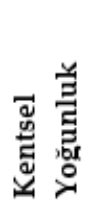 & $\begin{array}{l}\text { - Düşük nüfus yoğunluklu kentler } \\
\text { - Yatay genişleme } \\
\text { - Âdemi merkeziyetçilik yaklaşımı } \\
\text { - Kendi kendine yeten topluluk; kentsel } \\
\text { tarım- yerel değerler }\end{array}$ & $\begin{array}{l}\text { - } 50.000 \text { den az nüfusa sahip } \\
\text { - Yerel üretimin desteklenmesi } \\
\text { - Kente ait değerlerin iyileştirilmesi } \\
\text { - Kentsel tarım alanlarınun geliştirilmesi } \\
\text { ve yeni fikirler üretilmesi }\end{array}$ \\
\hline 范 & $\begin{array}{l}\text { - Mikromobilite araçlarınun kullanımı } \\
\text { - Yaya yollarının genişletilmesi } \\
\text { - Evrensel tasarım ilkelerine uygun } \\
\text { tasarım yaklaşımı }\end{array}$ & $\begin{array}{l}\text { - Mikromobilite araç kullanımının } \\
\text { teşviki ve altyapı sistemlerinin } \\
\text { kurgulanması } \\
\text { - Alternatif eko ulaşım planlaması } \\
\text { - Kapsayıcı ulaşım ağının sağlanması } \\
\text { - Kentsel yaşanabilirliğin artırılması }\end{array}$ \\
\hline 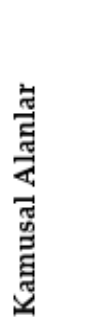 & $\begin{array}{l}\text { - Daha fazla yeşil ve temiz alan } \\
\text { kullanımı } \\
\text { - Kentin havasının temizliğinin } \\
\text { sağlanması } \\
\text { - Düzenlenebilen esnek kamusal } \\
\text { alanlar } \\
\text { - Kentsel boşlukların ve çöküntü } \\
\text { alanlarınun esnek tasarım ilkeleri } \\
\text { kriterlerine uygun değerlendirilmesi }\end{array}$ & $\begin{array}{l}\text { - Sosyal yeşil alanların iyileştirilmesi } \\
\text { - Hava kalitesi kontrolü, atık yönetimi } \\
\text { ve ışık kirliliği kontrolü } \\
\text { - Kentsel dirençlilik } \\
\text { - Kentsel peyzaj ve kültürel değerleri } \\
\text { korumak } \\
\text { - Çöküntü alanlannun yeniden } \\
\text { kullanılması }\end{array}$ \\
\hline$\underset{\Xi}{\Xi}$ & $\begin{array}{l}\text { - Çok işlevliliğe uygun mekânsal } \\
\text { kurgular } \\
\text { - Doğal aydınlatma ve havalandırma } \\
\text { kalitesinin arttırılması } \\
\text { - Yapısal, işlevsel ve kültürel esnekliğin } \\
\text { sağlanması }\end{array}$ & $\begin{array}{l}\text { - Yerel malzeme kullanımı } \\
\text { - Tarihi yapıların restorasyonu ve } \\
\text { yeniden işlevlendirilmesi } \\
\text { - Sürdürülebilir tasarım yaklaşımuna } \\
\text { uygunluk }\end{array}$ \\
\hline 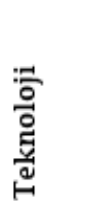 & $\begin{array}{l}\text { - Bilgi ve iletişim teknolojilerinin } \\
\text { kentsel yaşama entegrasyonu } \\
\text { - Çevresel, sosyal ve kentsel bağlamda } \\
\text { sürdürülebilirlik için teknolojik alt } \\
\text { yapıdan yararlanmak }\end{array}$ & $\begin{array}{l}\text { - İnternet ağının yayılması } \\
\text { - Bilgi iletişim teknolojilerinden } \\
\text { faydalanılarak sosyal } \\
\text { sürdürülebilirliğe katkı sunmak. } \\
\text { - Online çalışma imkânlarının } \\
\text { sağlanması }\end{array}$ \\
\hline
\end{tabular}

Açık hava kullanımını savunan yavaş kent yaklaşımı; sosyal alanların kent sakinlerinin sosyo-kültürel gelişimini destekleyecek, kalabalık oluşturmadan bunu sağlayabilecek ve esnek kullanımını teşvik edici olmasıyla antivirüs kente uyum göstermektedir. Antivirüs kentlerde konutların yapısal, iş- 
levsel ve kültürel esnekliğini sağlayacak önlemlerin alınması önemlidir. Yavaş kentler özellikle konut kullanımının arttı̆g 1 pandemi dönemlerinde sosyo-kültürel sürekliliğin korunmasını sağlayan yeniden işlevlendirme prensibine uygun çalışmaktadır. Virüsle savaşta konutların gün ışı̆̆ını kullanabilmesi, az katlı düzende olması ve kendi içinde sürekliliğini sağlayabilmesi yavaş kentlerdeki yerel malzeme kullanımına uygun, geleneksel konut yaklaşımını teşvik edici, az katlı yapıların düzenlenmesi prensiplerine uygundur. Konut kullanımı pandemi dönemlerinde bu kadar aktifken, işlerin online sistemle yürütülmesi, alışveriş, araştırma imkanlarının internet üzerinden interaktif araçlarla sağlanması gerekli olmaktadır. Yavaş kentlerin bilgi ve iletişim teknolojilerinin kullanımının sağlanmasında bu bağlamda geliştirdiği prensipler de antivirüs kentler için uygun bir zemin oluşturmaktadır.

Sonuçta antivirüs kentlerin gelecek yüzyılda daha fazla tartışılacak bir konu ve kavram olması oldukça yüksek olasılıktır. Hızla gelişen ve değişen dünyada sorunlara hızla çözüm üretecek tasarım kriterlerini oluşturmak mimarların, plancıların ve tasarımcıların sorumluluğundadır. Özellikle kentsel doku ve konut kapasiteleri göz önüne alındığında alternatif bir arayış, zaman yönünden ve sonuçları gözlenebilen örnekler yönüyle daha pratik bir tutum olmaktadır. Bu amaçla yapılan çalışmada da 1999 yılında kabul edilen "Yavaş Kent" kavramı üzerinden matris tablosu oluşturularak antivirüs kentlerin ihtiyaçlarına ne düzeyde cevap vereceği incelenmiştir. Tablo gözlem yoluyla incelendiğinde beklenen sonuç onaylanmıştır. Yavaş kentlerin de antivirüs kentler için uygun bir kent modeli olabileceği düşünülmektedir. 


\section{Extended Abstract}

\section{Slow City Approach in Planning Antivirus Cities}

\author{
Özge Ceylin Yildırım \\ ORCID: 0000-0002-8721-9552
}

\author{
Gamze Özmertyurt \\ ORCID: 0000-0002-0813-5503
}

Cities, which are living social organisms that are born, develop and die over time, are exposed to many stimuli throughout the process. At the beginning of these stimuli is the concept of health. Health is directly related to the city, both locally and globally. Urbanization is one of the most important variables affecting the health status of citizens. One of the main reasons for the changein the speed, scale and scope of urbanization in recent years is that it has turned into a global phenomenon. The increase in the urban population causes the living spaces of animal and human populations to be intertwined, and the interaction of people with each other the living creatures. This exposed humans to diseases for which they were not evolutionarily prepared and for which they were immune. These diseases are transmitted from animals to humans, from humans to humans in contact. This contagion is a social and spatial process, it spreads from place to place depending on the degree of mobility of people and the natural environment. Cities that host human interactions point to the connections between the formation of space, human and environmental behavior, and the spread of the epidemic. One of the closest examples of this is the Covid-19 pandemic, which affected the whole world in 2020. Various factors such as globalization, urbanization rate, population growth, global warming, climate change and interventions to the ecosystem that caused the pandemic are dragging their effects on cities into a future full of more and more complex and uncertainties. Daily life practices after the pandemic will not be the same as before; social habits and cultural activities will change. While cities are trying to cope with the epidemic, many questions need to be answered and new perspectives on how to plan and manage. 
Covid-19 spreads like computer viruses in a network and deeply affects the city and its inhabitants. In the digital world, new layers are added to design innovative solutions against virus attacks and adapt them to each new technology. However, studies to provide necessary protection against epidemics and to develop necessary approaches in urban planning are insufficient. In this context, it will be useful to understand how cities will be affected by the Covid-19 pandemic and to make predictions for the cities of the future based on the requirements of the age.

Based on the idea of antivirus in the digital world, this study made suggestions on how to antivirus urban planning in order to make cities more resilient when faced with any upcoming crisis and to prevent the spread of the epidemic. The suitability of the criteria of Smart Cities, Sustainable Cities and Healthy Cities, which have been previously studied in the search for alternative cities, which have been discussed recently, has been investigated. The city model proposed in the study is discussed in the context of Slow Cities. Since slow cities have emerged against rapid urbanization and globalization, they are more local-oriented, the production-consumption balance is provided, social and cultural values are developed, and an approach suitable for energy conservation and urban sustainability, they constitute an alternative as an antivirus city model. Antivirus Urban planning and design criteria have been proposed to provide a potential direction to urban planning in order to reduce and prevent risks arising from crises such as the Covid-19 pandemic. Urban planning and design criteria are considered as urban density, mobility, public life, housing, technology.

Planning and design criteria proposed for Antivirus urban planning can be predicted that new standards will be developed not only in dealing with the Covid-19 pandemic but also in architecture, urban planning, local and international administrations for new epidemics and crises that may arise in the future. As in past pandemics, temporary and fragmented urban solutions are not sufficient for future crises with the Covid-19 pandemic, which has emerged in the 21st century and whose future is speculative. In this context, the "Antivirus City" approach proposed in the study; It is a proactive city model by considering the formation of the city, its density, street designs, public and green spaces, residences and technological approaches. The fact that slow cities have a population of less than 50,000 and that they encourage agricultural production rather than a foreign-dependent consumption approach include approaches that can regulate their population. Encouraging the use of micromobility vehicles, which do not allow motor vehicle traffic, encouraging the use of bicycles and making appropriate urban arrangements ensure the restriction of urban mobility. Thus, it offers an approach 
that will reduce the contagion rate by preventing individuals from coming together at the same time as in the use of public transportation.

The slow city approach, which emphasizes the use of open air, providing spatial, functional and structural flexibility to support socio-cultural development, and the importance of using technologies, creates a suitable ground for antivirus cities.

As a result, it is highly probable that antivirus cities will be a topic and concept that will be discussed more in the next century. It is the responsibility of architects, planners and designers to create design criteria that will quickly produce solutions to problems in a rapidly developing and changing world. Especially considering the urban texture and housing capacities, an alternative search becomes a more practical attitude in terms of time and examples with observable results. In the study conducted for this purpose, a matrix table was created over the concept of "Slow City", which was accepted in 1999, and it was examined to what extent the antivirus would respond to the needs of cities. It has been demonstrated that slow cities can also be a suitable city model for antivirus cities.

\section{Kaynakça/References}

Ahlefeldt, F. (2020). Antivirus architecture as urban design. 24 Ocak 2021 tarihinde https://fritsahlefeldt.com/2020/04/28/antivirus-architecture-as-urban- design/ adresinden erişildi.

Alraouf, A.A. (2021), "The new normal or the forgotten normal: contesting COVID-19 impact on contemporary architecture and urbanism", Archnet-IJAR,14(3),1-22.

Allam, Z. ve Jones, D. S. (2020). Pandemic stricken cities on lockdown. Where are our planning and design professionals [now, then and into the future]?. Land use policy, 97, 1-5.

Allam, Z. ve Jones, D. S. (2021). Future (post-COVID) digital, smart and sustainable cities in the wake of 6G: Digital twins, immersive realities and new urban economies. Land use policy, 101, 105201.

Batty, M., (2014). The new science of cities.Cambridge: The MIT Press.

Belli, A. ve Aydın, A. (2016). Dünya sağlık örgütü sağlıklı kent projesi kapsamında Aksaray belediyesinin değerlendirilmesi, I. Uluslararası Aksaray Sempozyumu, 2729 Ekim 2016, Aksaray.

Bettaieb, D. M., Alsabban, R. (2020). Emerging living styles post-COVID-19: housing flexibility as a fundamental requirement for apartments in Jeddah. Archnet-IJAR: International Journal of Architectural Research,1-23.

Bibri, S. E., Krogstie, J. (2017). Smart sustainable cities of the future: An extensive interdisciplinary literature review. Sustainable cities and society, 31, 183-212.

Bozan, O (2015). Diyarbakır vilayetinde 1894-1895 kolera salgını ve etkileri. Türk Dünyası Araştırmaları,218, 219-240. 
Brenner, N. ve Schmid, C. (2015). Towards A new epistemology of the urban?. City, 19(23), $151-182$.

Cansaran, D. (2018). Küreselleşmeye aykırı bir yaşam biçimi "Sakin Kentler": Seferihisar örneği. İdealkent, 9(25), 885-908.

Capolongo, S., Rebecchi, A., Buffoli, M., Appolloni, L., Signorelli, C., Fara, G. M.ve D'Alessandro, D. (2020). COVID-19 and cities: From urban health strategies to the pandemic challenge. A decalogue of public health opportunities. Acta Bio Medica: Atenei Parmensis, 91(2), 13-22.

Cittaslow International, (2021).How to become. 28 Ocak 2021 tarihinde https://www.cittaslow.org/content/association adresinden erişildi.

Comune di Milano (2020). Milano 2020. 4 Şubat tarihinde https://www.comune.milano.it/aree-tematiche/partecipazione/milano-2020 adresinden erişildi.

Connolly, C., Ali, S. H. ve Keil, R. (2020). On the relationships between COVID-19 and extended urbanization. Dialogues in Human Geography, 10(2), 213-216.

Dietz, L., Horve, P. F., Coil, D. A., Fretz, M., Eisen, J. A. ve Van Den Wymelenberg, K. (2020). 2019 novel coronavirus (COVID-19) pandemic: built environment considerations to reduce transmission. Msystems, 5(2),1-15.

Ellin, N. (1999). Postmodern urbanism. New York: Princeton Architectural Press.

Eltarabily, S. ve Elghezanwy, D. (2020). Post-pandemic cities-the impact of COVID-19 on cities and urban design. Architecture Research, 10(3), 75-84.

Ghosh, R. (2020). Re-Thinking the city urban experience and the Covid-19 pandemic. 26 Ocak 2021 tarihinde www.versobooks.com/blogs/ 4648-rethinking-the-city-urban-experience-and-the-covid-19-pandemic adresinden erişildi.

Gilani, G., Turker, O.O. (2020). Assessing flexibility in real estate mass housing. Arquitetura Revista, 16 (1), 154-175.

Google (2021). COVID-19 Topluluk Hareket Raporu. 6 Şubat 2021 tarihinde https://www.gstatic.com/covid19/mobility/2021-01-31_TR_\%C4\%B0stanbul_Mobility_Report_tr.pdf adresinden erişildi.

Hamidi, S., Sabouri, S. ve Ewing, R. (2020). Does density aggravate the COVID-19 pandemic? Early findings and lessons for planners. Journal of the American Planning Association, 86(4), 495-509.

Hassanzadeh-Rad, A. ve Halabchi, F. (2020). Stadiums as possible hot spots for covid-19 Spread. Asian Journal of Sports Medicine, 11(2). doi: doi: 10.5812/asjsm.103178.

Hayward, A. C., Beale, S., Johnson, A. M., Fragaszy, E. B. ve Group, F. W. (2020). Public activities preceding the onset of acute respiratory infection syndromes in adults in England-implications for the use of social distancing to control pandemic respiratory infections. Wellcome open research, 5, 1-10.

Hawkins, A. J. (2020). Uber and Lyft generate 70 percent more pollution than trips they displace: study, Union of Concerned Scientists recommends more electric cars and pooled trips. 6 Şubat 2021 tarihinde https://www.theverge.com/2020/2/25/21152512/uber-lyft-climate-change-emissions-pollutionucs-study adresinden erişildi. 
Huber, V. (2006). The unification of the globe by disease? The International Sanitary Conferences on Cholera, 1851- 1894. The Historical Journal, 49,pp. 453-476.

Honey-RosesIsabelle, J., Anguelovski, I. ve Bohigas, J. (2020). The impact of COVID-19 on public space: an early review of the emerging questions-design, perceptions and in-equities. Cities and Health, 1-17.

Keleş, R. (1980). Kent terimleri sözlüğ̈̈. Ankara: Türk Dil Kurumu Yayınları.

Kemnitz, G. (1997). Wie macht man nachhaltige Stadtentwicklung akzeptabel? (Stadt mit Zukunft, 6.Forum der LpB 21. -23, pp. 113-117). März Haus auf der Alb, Bad Urach, Landeszentrale für politische Bildung Baden-Württemberg.

Kindervag, J. (2020). Cybersecurity lessons from the COVID-19 pandemic. 24 Ocak 2021 tarihinde www.securityroundtable.org/cybersecurity-lessons-from- the-coronavirus/ adresinden erişildi.

Khatoun, R., Zeadally, S. (2016). Smart cities: concepts, architectures, research opportunities. Communications of the ACM, 59(8), 46-57.

Knox, P.L. (2005). Creating ordinary places: slow cities in a fast world. Journal of Urban Design, 10, 1-11

Kunzmann, K. R. (2020). Smart cities after covid-19: Ten narratives. disP - The Planning Review, 56 (2), 20-31.

Lee, V. J., Ho, M., Kai, C. W., Aguilera, X., Heymann, D. ve Wilder-Smith, A. (2020). Epidemic preparedness in urban settings: new challenges and opportunities. The Lancet Infectious Diseases, 20(5), 527-529.

LePan, N. ve M. Routley. (2020). Visualizing the History of Pandemics. Visual Capitalist, COVID-19. 24 Ocak 2021 tarihinde https://www.visualcapitalist.com/history-ofpandemics-deadliest/ adresinden erişildi.

Li, Q., Guan, X., Wu, P., Wang, X., Zhou, L., Tong, Y., ... ,Feng, Z. (2020). Early transmission dynamics in Wuhan, China, of novel coronavirus-infected pneumonia. New England journal of medicine, 382(13),1199-1207.

Liu, L. (2020). Emerging study on the transmission of the Novel Coronavirus (COVID19) from urban perspective: Evidence from China. Cities, 103, 102759, 1-11.

Lubell, S. (2020). Commentary: Past pandemics changed the design of cities. Six ways covid-19 could do the same. 25 Ocak 2021 tarihinde https://www.latimes.com/entertainment-arts/story/2020-04-22/coronavirus-pandemics-architecture-urban-design adresinden erişildi.

Mayer, H. ve Knox, P. L. (2006). Slow cities: sustainable places in a fast world. Journal of urban affairs, 28(4), 321-334.

Megahed, N. A. ve Ghoneim, E. M. (2020). Antivirus-built environment: Lessons learned from Covid-19 pandemic. Sustainable Cities and Society, 61, 102350,1-9.

Miele, M. (2008). Cittáslow: Producing slowness against the fast life. Space and Polity, 12, 135-156.

Mishra, S.V., Gayen, A. ve Haque, S.M. (2020). COVID-19 and urban vulnerability in India. Habitat International, Vol. 103, 102230,1-11. 
Nieuwenhuijsen, M. J. (2020). Urban and transport planning pathways to carbon neutral, liveable and healthy cities; a review of the current evidence. Environment International, 140, 105661.

NOVA (2020). History of Quarantine. 24 Ocak 2021 tarihinde https://www.pbs.org/wgbh/nova/typhoid/quarantine.html adresinden erişildi.

Null, S. ve Smith, H. (2020). COVID-19 could affect cities for years: Here are 4 ways they're coping now. TheCityFix: World Resource Institute (WRI). 6 Şubat 2021 tarihinde https://hecityfix.com/blog/covid-19-affect-cities-years-4-ways-theyre-coping-now-schuyler-null-hillary-smith/ adresinden erişildi.

Özden, K. ve Özmat, M. (2014). Salgın ve kent: 1347 veba salgınının Avrupa'da sosyal, politik ve ekonomik sonuçları. İdealkent, 5(12), 60-87.

Panzac, D. (2011). Osmanlı Imparatorluğu'nda veba. İstanbul: Tarih Vakfi Yurt Yayınları.

Park, R. E. (1915), The city: Suggestions for the investigation of human behavior in the city evironment, The American Journal of Sociology, vol. 20, 5, 577-612.

Paris en Commun (2020). Le Programme D'anne Hidalgo. 4 Şubat tarihinde https://annehidalgo2020.com/le-programme/ adresinden erişildi.

Ratho, A. ve John, P. L. (2020). Rethinking Cities in a Post-COVID19 World. 1 Şubat 2021 tarihinde www.orfonline.org/research/rethinking-cities-in-a-post-covid19world-68736/ adresinden erişildi.

Rueda, S. (2019). Superblocks for the design of new cities and renovation of existing ones: Barcelona's case. Mark Nieuwenhuijsen and Haneen Khreis (Edt.), in Integrating human health into urban and transport planning (ss. 135-153). Switzerland: Springer, Cham.

Salama, A. M. (2020). Coronavirus questions that will not go away: interrogating urban and socio-spatial implications of COVID-19 measures. Emerald Open Research, 2,1-16.

Sassen, S. (2020). The city and The Virus. 24 Ocak 2021 tarihinde https://www.iberdrola.com/shapes-en/saskia-sassen-crisis-coronavirus adresinden erişildi.

Sharifi, A. (2020). Urban resilience assessment: mapping knowledge structure and trends. Sustainability, 12(15), 1-20.

Sinha, M. ve diğ. (2020). Towards mental health friendly cities during and after COVID19. Cities $\mathcal{E}$ Health, 1-4.

Şeker, M., Özer, A. ve Korkut, C. (Ed.). (2020). Küresel salgının anatomisi: İnsan ve toplumun geleceği. Türkiye Bilimler Akademisi, Ankara.

United Nations,(2001). A Globalizing World Global Report On Human Settlements. 17 Ocak 2021 tarihinde www.un.org/en/events/pastevents/pdfs/Cities_in_a_globalizing_world_2001.pdf adresinden erişildi.

United Nations, (2019). World Population Ageing 2019: Highlights. 17 Ocak 2021 tarihinde www. un.org/ en/development/desa/population/ publications/ pdf/ ageing/ worldpopulationageing2019-highlights.pdf adresinden erişildi. 
United Nations, (2020). Hedef 11: Şehirleri Kapsayıcı, Güvenli, Dayanıklı ve Sürdürülebilir Yapın. 1 Şubat 2021 tarihinde https://www.un.org/sustainabledevelopment/cities/ adresinden erişildi.

Tanyeli, U. (2017). Yikarak yapmak, anarşist bir mimarlık kuramı için altlık, İstanbul: Metis Yayınları.

Tekeli, İ. (2020). Salgınlar ve kentler sarmalında dünyanın geldiği nokta: Covid-19. Ö. F. Çolak (Der.), Salgın ekonomisi içinde (ss. 53-88). Ankara: Efil Yayınevi Yayınları.

Varlık, N. (2012). Tâun. Türkiye Diyanet Vakfi İslam Ansiklopedisi. (Cilt. 40, ss. 175-177). İstanbul.

Wheeler, S.M. (2004). Planning for sustainability: Creating livable, equitable, and ecological communities. New York: Routledge.

White, S. (2013). Osmanlı'da isyan iklimi erken modern dönemde Celâli İsyanları. N. Elhüseyni (Çev.). İstanbul: Melisa matbaacılık.

WHO (2020). Coronavirus disease pandemic. 10 Şubat 2021 tarihinde www.who.int/emergencies/diseases/novel-coronavirus-2019/technical-guidance adresinde erişildi. 